\title{
Roscovitine-induced apoptosis of H1299 cells depends on functional status of p53
}

\author{
J. SLOVACKOVA ${ }^{1}$, J. SMARDA ${ }^{2}$, J. SMARDOVA ${ }^{1,2 *}$ \\ ${ }^{1}$ Department of Pathology, University Hospital, Jihlavska 20, 62500 Brno, Czech Republic; ${ }^{2}$ Department of Experimental Biology, Faculty of \\ Science, Masaryk University, Kotlarska 2, 61137 Brno, Czech Republic
}

${ }^{*}$ Correspondence: janasmarda@seznam.cz

Received January 26, 2012 / Accepted April 16, 2012

\begin{abstract}
Roscovitine, an inhibitor of cyclin-dependent kinases, is promising anticancer agent. Its antiproliferative and cytotoxic effects can be mediated by the p53 signaling pathway. To define the role of p53 in roscovitine-induced cell response, we prepared H1299/p53 cell lines inducibly expressing specific variants of p53 (p53wt and hotspot R175H, temperature-dependent P98A, A159V, S215G, Y220C, Y234C mutants). In the presence of roscovitine, each cell line variant behaved in specific way reflecting activity of the p53 protein. Roscovitine decreased production of the cell cycle inhibitor p21 and induced apoptosis. This effect was the most efficient in cells expressing p53wt protein with full activity. The cell expressing partially and conditionally active p53 mutants responded to roscovitine less efficiently. The cells expressing p53 mutants A159V and Y234C were very sensitive to roscovitine but their response was clearly temperature-dependent. The cells expressing P98A, S215G and Y220C p53 mutants exhibited only weak sensitivity to roscovitine and underwent apoptosis in low frequency. In principle, each td p53 mutant responded to roscovitine in distinct way. We showed clearly that the impact of roscovitine on H1299 cells depends on functional status of p53 they produce. This suggests that patients with tumors exhibiting specific p53 variants can benefit from the roscovitine therapy.
\end{abstract}

Key words: roscovitine, apoptosis, p53 temperature-dependent mutants, $H 1299$ cells

Cancer cells accumulate mutations in genes coding for cell cycle regulators and DNA reparation proteins resulting in unscheduled proliferation and increased genomic and chromosomal instability [1]. Roscovitine (Seliciclib, CYC202) is a promising anticancer agent that can substantially limit tumor growth. Roscovitine is 2-R-(1-ethyl-2-hydroxyethylamino)-6benzylamino-9-isopropylepurine that competitively binds to the ATP-binding pocket of Cdk2 [2] and inhibits cyclin-dependent kinases, such as CDK1, CDK2, CDK5, CDK7, CDK9 as well as other kinases (e.g. ERK1, ERK2, pyridoxal kinase) with high selectivity [3,4]. Although the biological impact of roscovitine has been intensively studied, its mode of action is not clear. Multiple in vitro experiments proved its inhibitory effect on cell proliferation resulting from cell cycle arrest and/ or apoptosis but the components of the roscovitine-induced response are still ambiguous. The antiproliferative effect of roscovitine is mediated not only by CDKs $(1,2,5)$ but also by inhibition of RNA synthesis (CDK7 and 9) and disruption of ribosome biogenesis [5]. The importance of decreasing level of antiapoptotic Mcl-1 and increasing level of apoptotic PUMA and Noxa proteins for the roscovitine-induced apoptosis was reported [6] but the participation of tumor suppressor p53 remains controversial. Some studies reported that the roscovitine-induced cell response was p53-independent $[7,8]$ or the role of p53 was rather marginal $[9,10]$, the other groups $[11$, 12 ] showed that functional p 53 may be critical.

The p53 tumor suppressor participates in control of many essential cell functions, such as cell cycle, apoptosis, proliferation, differentiation, DNA repair, angiogenesis and many others. Therefore, p53 is significantly involved in determining the fate of a cell under various stress stimuli [13]. This central regulatory role is very often abrogated during cancerogenesis. The presence of mutated p53 was documented in about 50\% of human tumors. The majority of the mutations caused complete loss of the p53 standard functions. Some mutants may still remain partially functional, as temperature-dependent (td) mutants. Their function can be restored in permissive temperature. In our earlier studies, we investigated functional 
state, especially transactivation activity, of td p53 mutants in yeast [14] and in human non-small cell lung carcinoma H1299 cells [15]. In the present study, we analyzed the way how various td p53 variants affect response of H1299 cells to roscovitine. Production of p53wt, hotspot mutant R175H or td p53 mutants P98A, A159V, S215G, Y220C, and Y234C by these cells significantly affected frequency of roscovitineinduced apoptosis. Functional status of p53 and cultivation temperature was found important parameters for modulating the effects of roscovitine in cancer cells.

\section{Materials and methods}

Cell culture. Human non-small cell lung carcinoma p53-null H1299 cell line and its derivatives were cultured in RPMI-1640 medium (L-glutamine, $\mathrm{NaHCO}_{3}$ ) supplemented with $10 \%$ fetal calf serum and $1 \%$ penicillin/streptomycin at $5 \% \mathrm{CO}_{2}$ atmosphere and $32^{\circ}$ or $37^{\circ} \mathrm{C}$. To form H1299/p53 cells expressing p53 variants, the cells were co-transfected with p53pT-REx-DEST30 prepared according to the instructions of manufacturer using the Gateway technology (Invitrogen) and pcDNA6/TR repressing p53 expression (Invitrogen) in ratio 1:7 using Lipofectamine 2000 (Invitrogen). Stable transfectants were selected with $500 \mu \mathrm{g} / \mathrm{ml}$ Geneticin sulfate G418 (Gibco) and $5 \mu \mathrm{g} / \mathrm{ml}$ Blasticidin $\mathrm{S} \mathrm{HCl}$ (Invitrogen). Expression of $p 53$ in transfected cells was induced by tetracycline $(1 \mu \mathrm{g} / \mathrm{ml})$ [15]. The cells were treated with R-roscovitine (6-(benzylamino)2(R)-[1-(hydroxymethyl)propyl] amino]-9-isopropylpurine) diluted in DMSO (Sigma-Aldrich).

Immunoblotting. Harvested cells were washed with 1xPBS and boiled with reducing loading buffer. Equal amounts of the supernatant proteins were resolved by $10 \%$ sodium dodecylsulfate polyacrylamide gel electrophoresis (SDS-PAGE) and transferred onto a nitrocellulose membrane. Blots were blocked in $0.1 \%$ Tween 20 and 5\% low-fat milk in PBS for 1 hour, probed with anti-PARP-1 (215-228) (Alexis), antip21 antibody Cip1/WAF1 (BD Biosciences Pharminogen), anti-PCNA antibody PC10 as internal control and anti-p53 antibody DO-1 (kindly provided by B. Vojtěšek) at $4^{\circ} \mathrm{C}$. Blots were developed with Dako peroxidase-conjugated anti-rabbit or anti-mouse immunoglobulin using the ECL chemiluminiscent detection kit (Amersham Pharmacia Biotech).

Detection of cell death. Cells were seeded in microplates (5000 cells per well) and incubated with tetracycline at $32^{\circ}$ or $37^{\circ} \mathrm{C}$ over night to induce p53 expression. Then, roscovitine $(20 \mu \mathrm{M})$ was added and cell cultivation was extended for next 24 hours. Microplate was centrifuged and supernatant was processed by Cell Death Detection ELISA ${ }^{\text {PLus (Roche) }}$ quantitative sandwich enzyme immunoassay based on detection of mono- and oligonucleosomes produced by apoptotic DNA fragmentation. Each cell line was tested for apoptosis in presence or absence of roscovitine at $32^{\circ}$ and $37^{\circ} \mathrm{C}$. Relative frequency of apoptosis was normalized according to the rate of apoptosis found in the same cell line grown in the absence of roscovitine at $37^{\circ} \mathrm{C}$

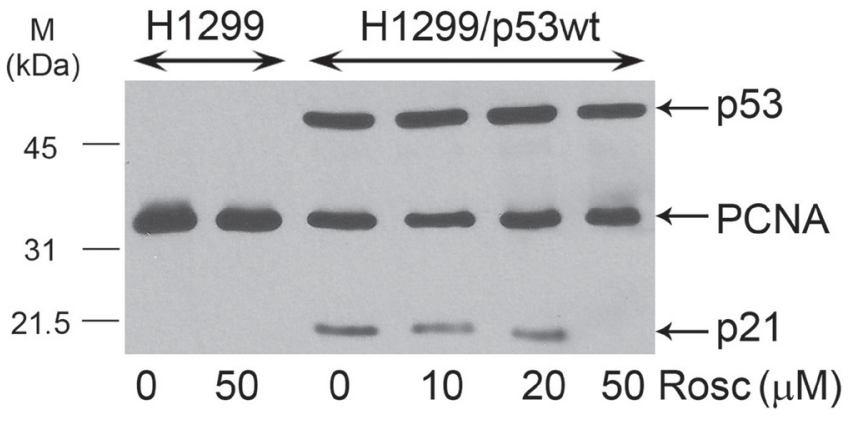

Figure 1. The effect of roscovitine on the levels of $\mathrm{p} 53$ and p21 proteins in $\mathrm{H} 1299 / \mathrm{p} 53$ cells.

H1299 and H1299/p53wt cells treated with roscovitine (0-50 $\mu \mathrm{M})$ for 24 hours. The proteins extracted from harvested cells were resolved by SDSPAGE and analyzed by immunoblotting using the p53- and p21-specific antibodies. PCNA was used as internal loading control.

\section{Results}

The aim of this study was to reveal the impact of temperature-dependent p53 mutants on the effects of roscovitine in human cells to evaluate the role of functional status of $\mathrm{p} 53$ and its temperature-dependent variants. To limit the influence of genetic background, we prepared several H1299 cell line variants inducibly expressing various forms of $\mathrm{p} 53$ : the positive control expressing $\mathrm{p} 53 \mathrm{wt}$, the negative control expressing fully inactive hot-spot mutant $\mathrm{R} 175 \mathrm{H}$, and td mutants P98A, A159V, S215G, Y220C, and Y234C. Temperature-dependency and transactivation abilities of the td p53 mutants were previously characterized both in yeast and human cells [14, 15]. The P98A mutant behaved as cold-sensitive, retaining lower activity at decreased temperature than at physiological temperature. The other td p53 mutants we chose for analysis were temperature-sensitive. They were inactive at physiological temperature but at least partially active at lower temperature. The A159V, S215G and Y234C mutants retained relatively high activity at permissive temperatures, while the Y220C mutant was almost inactive and capable of resuming its function in very limited way at temperatures lower than $32^{\circ} \mathrm{C}$.

Roscovitine regulates the level of $\mathrm{p} 21$ protein in $\mathrm{H} 1299$ cells producing specific p53 variants. First, we assessed an appropriate concentration of roscovitine to be used in our experiments. In human cells, including the MCF-7 cells, roscovitine is often used in $20 \mu \mathrm{M}$ concentrations. This concentration was shown to induce overproduction of the $\mathrm{p} 53$ protein as well as strong expression of its $p 21$ target gene [16]. H1299 and H1299/p53wt cells were cultivated in the presence of tetracycline $(1 \mu \mathrm{g} / \mathrm{ml})$ at $37^{\circ} \mathrm{C}$ overnight to induce p53 expression before addition of roscovitine in concentration range 0-50 $\mu \mathrm{M}$ for next 24 hours. Cells were harvested, the cell protein extracts resolved by SDS-PAGE and p53, p21 and PCNA proteins were detected by immunoblotting (Fig.1). H1299/p53wt cells produced high amount of the $\mathrm{p} 53$ protein both in the presence and absence of roscovitine. The level of 


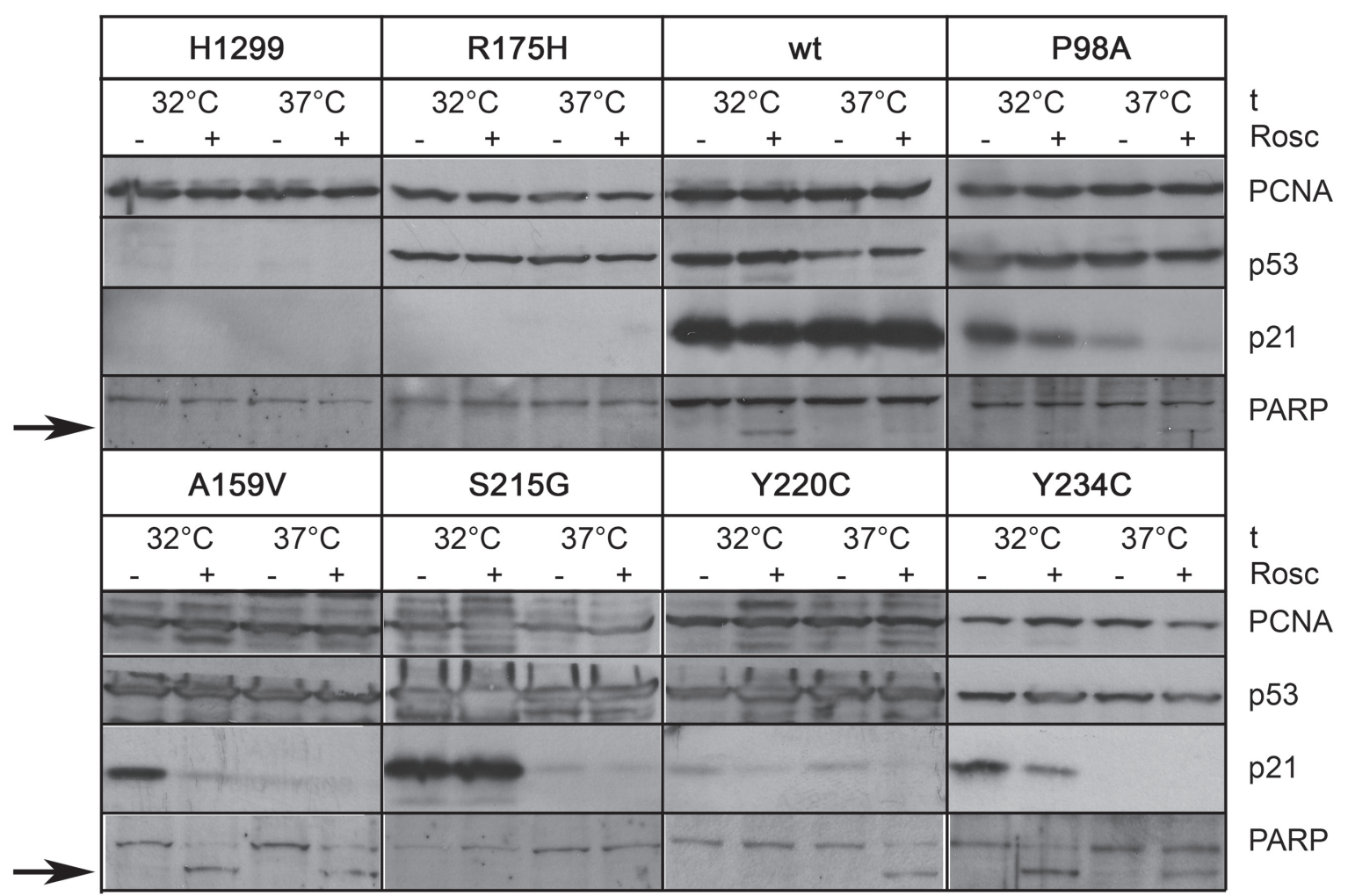

Figure 2. The extent of the p21 protein production and PARP-1 cleavage depends on the p53 functional status in roscovitine-treated H1299 cells. The H1299/p53 variants were treated with tetracycline overnight to induce p53 expression and incubated at 32 and $37^{\circ} \mathrm{C}$ before addition of roscovitine $(20 \mu \mathrm{M})$ for next 24 hours. Then, the cells were harvested, lysed, resolved by SDS-PAGE and immunoblotted using the p53-, p21-, and PARP-1-specific antibodies. The arrows indicate the $89 \mathrm{kDa}$ fragment of PARP-1. The PCNA was used as a loading control.

the $\mathrm{p} 21$ protein was high in $\mathrm{p} 53 \mathrm{wt}$-expressing cells untreated or treated with 10 and $20 \mu \mathrm{M}$ roscovitin. When treated with $50 \mu \mathrm{M}$ roscovitine, the cells failed to produce the p21 protein. In the absence of $\mathrm{p} 53$, roscovitine did not affect the level of the p21 protein in H1299 cells.

Subsequently, the effect of roscovitine on expression of p21 was studied in H1299 cells expressing td p53 mutants at 32 and $37^{\circ} \mathrm{C}$. The cells were cultivated in the presence of tetracycline at both temperatures overnight and then treated with $20 \mu \mathrm{M}$ roscovitine or left untreated for further 24 hours. Cells were harvested and the level of the $\mathrm{p} 21$ protein was assessed by immunoblotting (Fig.2). The cells producing p53 mutants A159V, S215G, Y234C exhibited clear temperature-dependent expression of $\mathrm{p} 21$. They produced very high level of the $\mathrm{p} 21$ protein at permissive temperature of $32^{\circ} \mathrm{C}$ and no $\mathrm{p} 21$ at $37^{\circ} \mathrm{C}$ in the absence of roscovitine. Addition of roscovitine resulted in significant decrease of the $\mathrm{p} 21$ protein produced in cells expressing the p53 mutants A159V and Y234C but not in cells expressing mutant $\mathrm{S} 215 \mathrm{G}$. The level of the $\mathrm{p} 21$ protein found in H1299 cells expressing almost inactive p53 mutant Y220C was very low; the $\mathrm{p} 21$ protein production was not affected by cultivation temperatures but it was further decreased upon treatment with roscovitine. Cells expressing cs p53 mutant
P98A and p53wt expressed p21 at both temperatures and they also responded to the roscovitine treatment by reduction of the p21 protein expression. Negative controls (the H1299 cells and the cells expressing hot-spot mutant $\mathrm{R} 175 \mathrm{H}$ ) did not express $\mathrm{p} 21$. These results confirmed that roscovitine reduces production of the $\mathrm{p} 21$ protein and this effect depends on functional status of the $\mathrm{p} 53$ protein.

Roscovitine triggers the p53-dependent apoptosis of H1299. The roscovitine-treated $\mathrm{H} 1299$ cells expressing some of the p53 variants exhibited morphological features resembling apoptosis. Therefore, we performed analysis of apoptosis, the programmed cell death process controlled by p53. First, we monitored cleavage of PARP-1 (poly(ADP-ribose) polymerase) to fragments of 89 and $24 \mathrm{kDa}$ by caspases occurring in early stages of apoptosis [17]. The cells expressing the p53 mutants and controls were cultivated with tetracycline overnight at both temperatures $\left(32\right.$ and $\left.37^{\circ} \mathrm{C}\right)$ and then treated or untreated with $20 \mu \mathrm{M}$ roscovitine for further 24 hours. The cells were harvested and their protein lysates were resolved by SDS-PAGE and the PARP-1 protein was detected by immunoblotting (Fig.2). In H1299 cells expressing p53wt, p53 A159V and Y234C, cleavage of PARP-1 $(89 \mathrm{kDa})$ occurred upon roscovitine treatment at both temperatures, but more efficiently at $32^{\circ} \mathrm{C}$ than at $37^{\circ} \mathrm{C}$. 


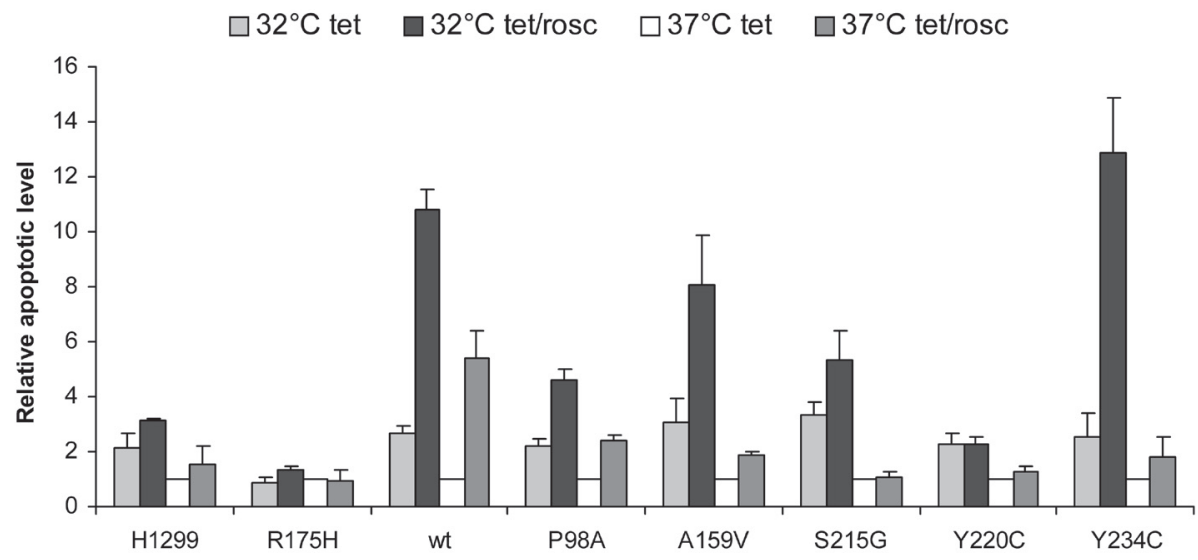

Figure 3. The roscovitine-induced apoptosis of $\mathrm{H} 1299$ cells depends on the p53 variant and cultivation temperature.

The H1299/p53 variants were treated with tetracycline overnight to induce p53 expression at 32 and $37^{\circ} \mathrm{C}$ before addition of roscovitine $(20 \mu \mathrm{M})$ for next 24 hours. Harvested cells were centrifuged and supernatants were analyzed by the apoptosis detection by kit (Cell Death Detection ELISA ${ }^{\text {PLus }}$, Roche) monitoring apoptotic DNA fragmentation. Data obtained were normalized according to the value of apoptosis found in the cell line cultivated in absence of roscovitine at $37^{\circ} \mathrm{C}$ (white columns are equal to one). Error bars indicate standard deviations in three independent experiments.

In cells expressing p53 mutants P98A and Y220C, only weak cleavage of PARP-1 to the $89 \mathrm{kDa}$ fragment was detected at $37^{\circ} \mathrm{C}$. The $\mathrm{H} 1299$ cells and the cells expressing hot-spot mutant $\mathrm{R} 175 \mathrm{H}$ (negative controls) and ts mutant S215G did not exhibit cleavage of PARP-1.

Next, we quantified frequency of apoptosis using a functional test, the Cell Death Detection ELISA ${ }^{\text {PLUS }}$ kit (Roche). This assay determines apoptosis according to the DNA fragmentation by sandwich ELISA. The H1299/p53 cell lines were seeded into 96-well microplate (5000 cells per well) and incubated with tetracycline at 32 or $37^{\circ} \mathrm{C}$ overnight before addition of $20 \mathrm{uM}$ roscovitine for next 24 hours. The cells were processed for detection of apoptosis as recommended by manufacturer. The results of this assay confirmed our earlier observation. Roscovitine induced apoptosis of H1299 cells reflecting the type of expressed p53 variant (Fig.3). Generally, apoptosis was increased at $32^{\circ} \mathrm{C}$. This effect presumably resulted from suboptimal cultivation conditions at lower temperature. Even $\mathrm{H} 1299 / \mathrm{p} 53-$ null cells slightly raised rate of apoptosis at $32^{\circ} \mathrm{C}$. The highest proportion of apoptotic cells was detected in variants expressing the $\mathrm{p} 53$ mutants $\mathrm{A} 159 \mathrm{~V}$ and $\mathrm{Y} 234 \mathrm{C}$ and $\mathrm{p} 53 \mathrm{wt}$ at $32^{\circ} \mathrm{C}$. In case of the mutant $\mathrm{Y} 234 \mathrm{C}$, the level of apoptosis of cells expressing the Y234C mutant was even higher than in variants expressing p53wt. The mutants P98A and S215G exhibited only low frequency of apoptosis. At $37^{\circ} \mathrm{C}$, only roscovitine-treated cells expressing p53wt underwent apoptosis in substantial extent. In the cell line variants expressing td p53 mutants, frequency of apoptosis was lower at non-permissive than at permissive temperature. Roscovitine did not induce any apoptotic DNA fragmentation in H1299/Y220C. This mutant behaved similarly in the negative controls.

Cell Death Detection ELISA ${ }^{\text {PLUS }}$ kit can distinguish apoptotic cells from necrotic ones. We did not observe necrotic cells in the roscovitine-treated H1299/p53 cells undergoing apoptosis. Low level of necrosis was observed only at $32^{\circ} \mathrm{C}$ in all used H1299 cell lines probably due to suboptimal cultivation temperature (data not shown).

We can conclude that only fully functional p53wt provides the cells with ability to respond efficiently to roscovitine. The response of partially and conditionally active td p53 mutants to roscovitine is less efficient. The cells expressing p53 mutants A159V and Y234C were very sensitive to roscovitine but their response was clearly temperature-dependent: roscovitine induced strong apoptotic response only at $32^{\circ} \mathrm{C}$. Substantially higher level of cleaved PARP-1 and of nucleosomal fragmentation was detected at permissive than at physiological temperature. Cells expressing P98A mutant were only weakly sensitive to roscovitine, apoptotic markers were mildly increased at both temperatures. The cells expressing mutant S215G increased nucleosomal fragmentation at $32^{\circ} \mathrm{C}$ but no apoptotic PARP-1 fragmentation upon the roscovitine treatment. The cells expressing the Y220C p53 were relatively resistant to roscovitine and mediated only subtle apoptotic cell response. Only H1299/p53wt underwent significant apoptosis at physiological temperature $37^{\circ} \mathrm{C}$. Negative controls, such as the roscovitine-treated cells expressing null or fully inactive $\mathrm{R} 175 \mathrm{H}$ mutant p53 did not exhibit any hallmarks of apoptosis, such as the PARP-1 cleavage and intranucleosomal fragmentation.

The results obtained from two independent approaches to detect apoptotic cell death revealed that the impact of roscovitine on H1299 cells depends on functional status of p53. In principle, each td p53 mutant responded to roscovitine in a distinct way.

\section{Discussion}

Roscovitine has entered clinical trials as very potent anticancer agent suitable for treatment of different cancers 
(lung, breast and B-cell malignancies) (www.cyclacel.com). Its antiproliferative and cytotoxic effects were described in various cancer cell lines in many in vitro and in vivo studies. Depending on the tumor tissue specificity it can trigger different scenarios ranging from cell senescence and cell cycle arrest [18] to mitotic catastrophe [19] and/or apoptosis [12, 10]. Roscovitine can modulate cell fate in various ways. Besides the direct inhibition of CKDs resulting in cell cycle arrest and inhibition of gene transcription, it can regulate expression of anti-apoptotic genes (such as $b c l-2, m c l-1, X I A P$, survivin), proapoptotic genes, such as PUMA, Noxa and cell cycle regulator genes, such as $(p 21, p 27)[5,6,9]$. The role of tumor suppressor and transcriptional factor $\mathrm{p} 53$ in the roscovitine-induced cell response is contradictory and still has not been satisfactory resolved. Depending on experimental set up, the type of cancer cells and doses of roscovitine, the researchers reported conflicting observations. Some of them identified greater cytotoxic potency of roscovitine against cells with functional p53 [11, $12,16,20]$. In contrast, other groups described only marginal role of p53 in cell response to roscovitine $[9,10]$. There are also reports declaring that roscovitine is a potent anticancer agent regardless of the functional status of p53 [7, 8].

In our experimental system, certain p53 variants were inducibly expressed in H1299 non-small cell lung carcinoma cells and their role in mediating the effects of roscovitine were tested. Our results document that p53 is an essential regulator of the cell response to roscovitine. As an inhibitor of CDKs, roscovitine primarily exhibits its antiproliferative effect that could be supported or followed by expression of other cell cycle inhibitors, such as p21 [21]. Thus, we first analyzed an impact of roscovitine on expression of p21. It is obvious from our previous studies that $\mathrm{p} 53$ preferentially transactivates the genes involved in cell cycle regulation (e.g. p21) rather than pro-apoptotic genes (e.g. bax) [15]. The $p 21$ gene possesses high affinity promoter, whereas the bax promoter has low affinity for p53 [22]. Surprisingly, we observed significant decrease of the $\mathrm{p} 21$ protein in roscovitine-treated $\mathrm{H} 1299$ cells expressing p53wt and P98A, A159V, Y234C p53 mutants, although there are studies demonstrating increased expression of p21 upon the roscovitine treatment $[16,21]$. On the other hand, the p21 expression might depend on dose of roscovitine. Higher doses of roscovitine were found to downregulate $p 21$ in ACHN renal carcinoma cells [12] and in MCF-7 and RPMI-8226 cells presumably due to inhibition of general rate of transcription [11].Zhang's group showed that roscovitine-induced decrease of p21 resulted from apoptotic cleavage of the p21 protein by caspase 3 in A549 non-small cell lung carcinoma cells [23]. Apoptotic pathway is activated by p53 in cells exposed to severe stress stimuli and is preferred in anticancer therapy. We followed the PARP-1- and internucleosomal DNA fragmentation in H1299 cells expressing several forms of p53, such as p53wt, A159V and Y234C mutants and treated them with roscovitine. We showed that the presence of $\mathrm{p} 53$ was required for the roscovitine-induced apoptosis. When td p53 mutants were expressed in H1299 cells, the roscovitine-induced ap- optosis also occurred in the temperature-dependent manner. An increased expression of apoptotic markers in these cells negatively correlated with the $\mathrm{p} 21$ protein. The higher rate of the PARP-1 cleavage was detected, the lower amount of the p21 protein was found in the cells. These results clearly support the results published earlier [23].

Roscovitine can induce apoptosis of $\mathrm{H} 1299$ cells expressing p53wt at all temperatures we tested but each td p53 mutant responded to roscovitine uniquely reflecting the cultivation temperature. The $\mathrm{A} 159 \mathrm{~V}$ and $\mathrm{Y} 234 \mathrm{C}$ ts $\mathrm{p} 53$ mutants were the most sensitive to roscovitine at permissive temperature. The cells expressing the cs p53 mutant P98A exhibited the apoptotic markers at both temperatures even though not in the same extent as the cells expressing the p53wt. In contrast, the cells expressing the S215G and Y220C p53 ts mutant were almost resistant to roscovitine. They behaved similarly as negative controls. We showed earlier that individual td p53 mutant is unique concerning its temperature-dependency, functions, transactivation rates and reactivation abilities. These features are predetermined by the type and/or position of mutation in the $\mathrm{p} 53$ gene. The rules and relations between p53 mutation and its functional outcome are not clearly understood. For example, it is difficult to predict the reactivation potential of the p53 mutant from its transactivation activity. The S215G p53 mutant is the second most active mutant of our collection but is almost resistant to roscovitine. On the other hand, the A159V and Y234C mutants exhibit intermediate transactivation activity and are prone to reactivation. However, the td p53 mutants seem to be more sensitive to many p53-reactivating compounds $[24,25,26,27]$ and this ability depends on specificity of individual mutation.

Importantly, we showed that some td p53 mutants possess greater potential to be reactivated by either temperature shift or chemical compounds than others. The mutants that were tested for their susceptibility to roscovitine were selected from the large panel of td p53 mutants that we have collected during many years of routine diagnostics of the p53 functional status in tumor samples. Four mutants (ts A159V, S215G, Y234C and cs P98A) were selected because of their confirmed ability to be reactivated by amifostine, the p53-reactivating agent that we tested previously [14]. The A159V and Y234C mutants retain high level of transactivation activities at permissive temperatures and are the most successful respondents to amifostine. The S215G mutant is one the most active ts mutants, although its reactivation by amifostine is only marginal. The cs mutant P98A with partial activity at permissive as well as restrictive temperature responds well to amifostine. The Y220C is the ninth frequent p53 mutant found in human cancers and is almost inactive mutant that did not respond to amifostine.

It seems that transactivation activity of p53 mutants does not predict their reactivation. The most active (S215G) and the least active (Y220C) mutants can be reactivated neither by amifostine nor by roscovitine. Surprisingly, the A159V and Y234C mutants are very good responders to both $\mathrm{p} 53$ reactivating compounds, although both compounds reactivate 
p53 through completely different ways. Amifostine acts as cytoprotective adjuvant detoxifying reactive metabolites of platinum and alkylating agents and scavenging free radicals. Presumably, the amifostine might directly stabilize the p53 protein structure, stimulate the p53 DNA-binding activity and positively regulate the p53 signaling pathway through JNK kinase [28]. The cross-talk of roscovitine and p53 signaling pathways has not been satisfactory resolved yet. The p53 accumulation and stabilization can be achieved by inhibition of CDK7 and 9 resulting in decreased transcription of p53 negative regulators [5]. Altogether, our experiments with roscovitine and amifostine showed that some td p53 mutants possess considerable reactivation potential and could become successful targets of p53-reactivating therapy.

Acknowledgements: This work was supported by grant NS/104483/2009 of the Internal Grant Agency of the Ministry of Health of the Czech Republic.

\section{References}

[1] MALUMBRES M, BARBACID M. Cell cycle CDKs and cancer: a changing paradigm. Nat Rev Cancer 2009; 9: 153-166. http: //dx.doi.org/10.1038/nrc2602

[2] DE AZEVEDO WF, LECLERC S, MEIJER L, HAVLICEK L, STRNAD M et al. Inhibition of cyclin-dependent kinases by purine analogues: crystal structure of human cdk2 complexed with roscovitine. Eur J Biochem 1997; 243: 518-526. http: //dx.doi.org/10.1111/j.1432-1033.1997.0518a.x

[3] MEIJER L, BORGNE A, MULNER O, CHONG JPJ, BLOW JJ et al. Biochemical and cellular effects of roscovitine, a potent and selective inhibitor of the cyclin-dependent kinases cdc2, cdk2 and cdk5. Eur J Biochem 1997; 243: 527-536. http: //dx.doi.org/10.1111/j.1432-1033.1997.t01-2-00527.x

[4] BACH S, KNOCKAERT M, REINHARDT J, LOZACH O, SCHMITT $S$ et al. Roscovitine targets, protein kinases and pyridoxal kinase. J Biol Chem 2005; 280: 31208-31219. http: //dx.doi.org/10.1074/jbc.M500806200

[5.] KRYSTOF V, ULDRIJAN S. Cyclin-dependent kinase inhibitors as anticancer drugs. Curr Drug Targets 2010; 11:291-302. http: //dx.doi.org/10.2174/138945010790711950

[6] HALLAERT DYH, SPIJKER R, JAK M, DERKS IAM, ALVES $\mathrm{NL}$ et al. Crosstalk among Bcl-2 family members in B-CLL: seliciclib acts via the Mcl-1/Noxa axis and gradual exhaustion of Bcl-2 protection. Cell Death Differ 2007; 14: 1958-1967. http: //dx.doi.org/10.1038/sj.cdd.4

[7] ALVI AJ, AUSTEN B, WESTON VJ, FEGAN C, MACCALLUM D et al. A novel CDK inhibitor, CYC202 (R-Roscovitine), overcomes the defect in p53-dependent apoptosis in B-CLL by down-regulation of genes involved in transcription regulation and survival. Blood 2005; 105: 4485-4491.

[8] DEY A, WONG ET, CHEOK CF, TERGAONKAR V, LANE DP. R-Roscovitine simultaneously targets both the p53 and NF- $\kappa B$ pathways and causes potentiation of apoptosis: implications in therapy. Cell Death Differ 2008; 15: 263-273. http: //dx.doi.org/10.1038/sj.cdd.4402257
[9] MACCALLUM DE, MELVILLE J, FRAME S, WATT K, ANDERSON S et al. Seliciclib (CYC202, R-Roscovitine) induces cell death in multiple myeloma cells by inhibition of Mcl-1. Cancer Res 2005; 65: 5399-5407. http: //dx.doi. org/10.1158/0008-5472.CAN-05-0233

[10] GARROFE-OCHOA X, COSIALLS AM, RIBAS J, GIL J, BOIX J. Transcriptional modulation of apoptosis regulators by roscovitine and related compounds. Apoptosis 2011; 16: 660-670. http: //dx.doi.org/10.1007/s10495-011-0603-3

[11] PAPRSKAROVA M, KRYSTOF V, JORDA R, DZUBAK P, HAJDUCH $\mathrm{M}$ et al. Functional p53 in cells contributes to the anticancer effect of the cyclin-dependent kinase inhibitor roscovitine. J Cell Biochem 2009; 107: 428-437. http: //dx.doi. org/10.1002/jcb.22139

[12] ISHIMARU T, LAU J, JACKSON AL, MODIANO JF, WEISS RH. Pharmacological inhibition of cyclin dependent kinases causes p53 dependent apoptosis in renal cell carcinoma. J Urology 2010; 184: 2134-2149. http: //dx.doi.org/10.1016/ j.juro.2010.06.088

[13] VOUSDEN KH, LANE DP. p53 in health and disease. Mol Cell Biol 2007; 8: 275-283.

[14] GROCHOVA D, VANKOVA J, DAMBORSKY J, RAVCUKOVA B, SMARDA J et al. Analysis of transactivation capability and conformation of $\mathrm{p} 53$ temperature-dependent mutants and their reactivation by amifostine in yeast. Oncogene 2008; 27 : 1243-1252. http: //dx.doi.org/10.1038/sj.onc.1210748

[15] SLOVACKOVA J, GROCHOVA D, NAVRATILOVA J, SMARDA J, SMARDOVA J. Transactivation by temperature-dependent p53 mutants in yeast and human cells. Cell Cycle 2010; 9: 2141-2148. http: //dx.doi.org/10.4161/ cc. 9.11 .11808

[16] KOTALA V, ULDRIJAN S, HORKY M, TRBUSEK M, STRNAD M et al. Potent induction of wild-type p53-dependent transcription in tumour cells by a synthetic inhibitor of cyclin-dependent kinases. Cell Mol Life Sci 2001; 58: 1333-1339. http: //dx.doi.org/10.1007/PL00000944

[17] KAUFMANN SH, DESNOYERS S, OTTAVIANO Y, DAVIDSON NE, POIRIER GG. Specific proteolytic cleavage of poly(ADP-ribose) polymerase: an early marker of chemotherapy-induced apoptosis. Cancer Res 1993; 53: 3976-3985.

[18] CRESCENZI E, PALUMBO G, BRADY HJM. Roscovitine modulates DNA repair and senescence: implications for combination chemotherapy. Clin Cancer Res 2005; 11: 8158-8171. http: //dx.doi.org/10.1158/1078-0432.CCR-05-1042

[19] GALIMBERTI F, THOMPSON SL, LIU X, LI H, MEMOLI $\mathrm{V}$ et al. Targeting the cyklin E-Cdk-2 complex represses lung cancer growth by triggering anaphase catastrophe. Clin Cancer Res 2010; 16: 109-120. http: //dx.doi.org/10.1158/ 1078-0432.CCR-09-2151

[20] MCCLUE SJ, BLAKE D, CLARKE R, COWAN A, CUMMINGS L et al. In vitro and In vivo antitumor properties of the cyclin dependent kinase inhibitor CYC202 (R-Roscovitine). Int J Cancer 2002; 102: 463-468. http: //dx.doi.org/10.1002/ ijc. 10738

[21] APPLEYARD MV, O'NEILL MA, MURRAY KE, PAULIN FE, BRAY SE et al. Seliciclib (CYC202, R-Roscovitine) enhances 
the antitumor effect of doxorubicin in vivo in a breast cancer xenograft model. Int J Cancer 2009; 124: 465-472. http: //dx.doi.org/10.1002/ijc.23938

[22] MENENDEZ D, INGA A, RESNICK MA. The expanding universe of p53 targets. Nat Rev Cancer 2009; 9: 724-737. http: //dx.doi.org/10.1038/nrc2730

[23] ZHANG T, JIANG T, ZHANG F, LI C, ZHOU YA et al. Involvement of p21WAf1/Cip1 cleavage during roscovitineinduced apoptosis in non-small cell lung cancer cells. Oncol Rep 2010; 23, 1: 239-245.

[24] FOSTER BA, COFFEY HA, MORIN MJ, RASTINEJAD F. Pharmacological rescue of mutant p53 conformation and function. Science 1999; 286: 2507-2510.

[25] FRIEDLER A, HANSSON LO, VEPRINTSEV DB, FREUND SM, RIPPIN TM et al. A peptide that binds and stabilizes p53 core domain: Chaperone strategy for rescue of oncogenic mutants. Proc Nat Acad Sci USA 2002; 99: 937-942. http: //dx.doi.org/10.1073/pnas.241629998

[26] NORTH S, PLUQUET O, MAURICI D, EL-GHISSASSI F, HAINAUT P. Restoration of wild-type conformation and activity of a temperature-sensitive mutant of p53 (p53(V272M)) by the cytoprotective aminothiol WR1065 in the esophageal cancer cell line TE-1. Mol Carcinog 2002; 33: 181-188. http: //dx.doi.org/10.1002/mc.10038

[27] BOECKLER FM, JOERGER AC, JAGGI G, RUTHERFORD TJ, VEPRINTSEV DB et al. Targeted rescue of a destabilized mutant of p53 by an in silico screened drug. Proc Nat Acad Sci USA 2008; 105: 10360-10365. http: //dx.doi.org/10.1073/ pnas.0805326105

[28] GROCHOVA D, SMARDOVA J. Antimutagenic and cytoprotective effects of amifostine: the role of p53. J Appl Biomed 2007; 5: 171-178. 